\title{
Volume techniques for estimating standing and lying dead wood in Okomu national park, Edo state, Nigeria
}

\begin{abstract}
Dimensions are essential characteristics to estimate standing and lying dead wood volumes. Therefore, the study is aimed at estimating standing and lying dead wood volumes with a view to identify the variation that exist amongst volume equations in Okomu National Park. Hossfeld's equation and other volume equations should be considered suitable for estimating volume of standing and lying deadwood, depending on the available variable.
\end{abstract}

Keywords: dead wood, volume techniques, tree species, estimation
Volume 9 Issue 3 - 2020

\author{
Aghimien E.V,' Osikabor B,' Adedeji M.S, ${ }^{2}$ \\ Adams O.T ${ }^{2}$ \\ 'Federal college of forest resources management, Nigeria \\ ${ }^{2}$ Federal College of forestry, Nigeria
}

Correspondence: Ehimwenma Victor Aghimien, Federal College of Forest Resources Management, Moist Forest Research Station, Forestry Research Institute of Nigeria, Edo State,Tel +234703 1238830, Email aghimien4@yahoo.com

Received: May 14, 2020 | Published: June 15, 2020

\section{Introduction}

Dead wood plays a variety of roles in rainforest ecosystem through its influence on biological, physical and chemical processes ${ }^{1-3}$ directly or indirectly it provides a substrate or host for a wide range of organisms, particularly fungi and invertebrates; cavities formed by rot are used as nesting sites or shelter by many vertebrates; and decaying logs may act as safe sites for seedling germination. Standing dead trees otherwise known as snags include large standing dead individual trees killed by disease, lightning strikes, drought, water logging, or pollution as well as smaller standing trees killed by shading during the early growth of densely stocked stands, while lying dead wood are the falling top and branches that are missing from a stand dead trees. Lying deadwood may sometimes be a whole standing dead tree that has been wind thrown. However, lying dead wood can vary in size from large trunks to small twigs; it may be high in the canopy or lying on the forest floor ${ }^{4,5}$ Volume of dead wood in forests can be measured quite easily on small inventory plots. However, the demand for such data is quite new and many countries are just implementing the measurement into their National Forest Inventories (NFI). Dimensions are necessary attributes to calculate approximate volume of deadwood. ${ }^{6}$ According to Stokland et al., ${ }^{6}$ diameter is one of the most important biodiversity attributes of dead wood, since a majority of species colonizing dead wood respond to its value. While some species prefer small diameters up to $20 \mathrm{~cm}$, other species colonize only dead wood with diameters greater than $20 \mathrm{~cm}$ or even $40 \mathrm{~cm} .{ }^{6}$ The identification of standing dead tree is quite easy, but as decomposition advances, the identification becomes more difficult. ${ }^{7}$ Standing dead tree longevity is determined in large part by species and sizes. Dead wood volume has been assessed in different ways by different researchers and there is a clear and wide difference in the estimates made by different scientists and foresters. ${ }^{8}$ However, precise and accurate estimates of volume are essential for decision making process by policy makers. Therefore, the study is aimed at estimating standing and lying dead wood volumes with a view to identify the variation that exists amongst volume equations in Okomu National Park.

\section{Materials and methods}

\section{Description of the study area}

Okomu National Park is located between Latitude $60^{\circ} 15^{\prime} 0$ " $\mathrm{N}$ and $60^{\circ} 25^{\prime} 0^{\prime \prime} \mathrm{N}$ and longitude of $50^{\circ} 90^{\prime} 0^{\prime \prime} \mathrm{E}$ and $50^{\circ} 23^{\prime} 0^{\prime \prime} \mathrm{N}$. The Park covers an area of $202.24 \mathrm{~km}^{2} .^{9}$ Okomu National Park, formerly known as Okomu Wildlife Sanctuary, is a forest block within Okomu Forest Reserve $\left(1,082 \mathrm{~km}^{2}\right)$. The reserve is located in Ovia SouthWest of Edo State, and is $50 \mathrm{~km}$ west of the State's capital - Benin City. Okomu National Park was an initial $66 \mathrm{~km}^{2}$ sanctuary. However, the Nigerian Conservation Foundation (NCF) extended it to 114 $\mathrm{km}^{2}$ by adding a $1.6 \mathrm{~km}$ wide buffer zone. Okomu National Park is a rain forest habitat for several endangered flora and fauna. Despite the small size of the National Park, Okomu National park is fast becoming an attractive ecotourism destination being characterized by its rich rainforest biodiversity. The park holds a small fragment of the rich forest that once covered the region, and is the last habitat for many endangered species. It continues to shrink as villages encroach on it, and is now less than one third of its original size. Powerful corporations are involved in Okomu National Park development and logging concessions around the park, which also pose a threat. ${ }^{9}$

\section{Sampling design and sample size}

The estimation of standing and lying dead wood volumes within the National Park, Okomu National Park is divided into four ranges which include; A (Iguowan range), B (Arakhuan range), C (Julius Creek range) and D (Baubui Creek range). Simple random sampling technique was used to select three (3) Temporary Sample Plots (TSPs) from each of the four (4) ranges, respectively. A total of Twelve (12) TSPs of $20 \mathrm{~m} \times 20 \mathrm{~m}(0.04 \mathrm{ha})$ in size were randomly laid in the rainforest ecosystem.

\section{Standing and lying dead wood}

Standing and lying dead wood were measured for diameters and heights/lengths in the corresponding TSPs, according to tree sizes. 
Three (3) diameter measurements were taken using the Criterion RD 1000 laser dendrometer and diameter tape; diameter at base $\left(\mathrm{D}_{\text {base }}\right)$; diameter at breast height $(\mathrm{dbh})$, diameter at top $\left(\mathrm{D}_{\text {top }}\right)$, standing Bole Height $\left(\mathrm{H}_{\mathrm{b}}\right)$ and lying dead wood Length $(\mathrm{L})$ were measured using TruPulse 200B ranger finder and 50m measuring tape. All section of the lying dead wood outside the TSPs boundaries were ignored. Standing and lying dead wood in all of the TSPs with a diameter $\geq$ $10 \mathrm{~cm}$ and lying dead wood length $\geq 1 \mathrm{~m}$ were measured.

\section{Estimation of standing and lying dead wood volume}

Many dead wood inventory methods require estimates of individual volume in order to obtain an estimate of dead wood volume per ha. This presents special challenges for dead wood above and beyond those that arise for live trees or merchantable logs. ${ }^{10}$ Having one or more accurate measurements of cross-sectional area does not guarantee an accurate estimate of the volume of individual dead wood pieces; these measurements must be combined in such a way as to produce an accurate of the average cross-sectional area of the pieces. Foresters have long employed volume formulae derived from classical quadrature. It is a mathematical technique used for evaluating an integral without an exact formula. Quadrature rules used in forestry include the familiar Huber's, Smalian's, and Newton's formulae. ${ }^{11}$ Volume of bole sections are often calculated using Newton's, Smalian's, and Huber's formulae, or alternatively by using the geometric equation for the truncated cone, and Hossfeld's equation. They are mathematically expressed as follows:

$$
\begin{aligned}
V= & \pi \cdot H_{b}\left(\frac{D_{\text {base }}^{2}+\left(4 . D_{\text {middle }}^{2}\right)+D_{\text {top }}^{2}}{24}\right) \\
& \ldots \ldots \ldots \ldots \ldots \ldots \ldots \ldots \ldots \ldots \ldots \ldots \ldots \ldots \ldots \ldots \ldots \ldots \ldots \ldots \ldots \ldots \ldots \ldots \ldots \\
V= & \frac{\pi \cdot H_{b}}{12}\left(D_{\text {base }}^{2}+\left(D_{\text {base }} . D_{\text {top }}\right)+D_{\text {top }}^{2}\right)
\end{aligned}
$$

..(Geometric equation for the truncated cone eqn. 2)

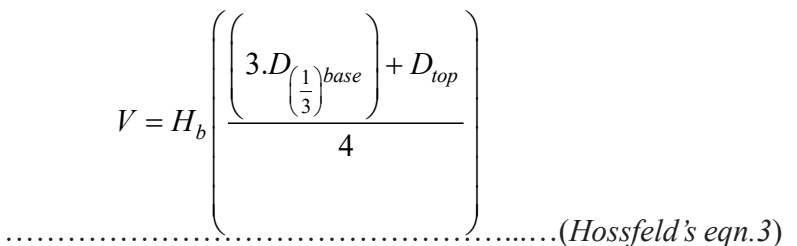

$$
V=\pi \cdot H_{b}\left(\frac{D_{\text {base }}^{2}+D^{2}{ }_{\text {top }}}{8}\right)
$$

(Smalian's eqn. 4)

$$
V=\pi \cdot H_{b}\left(\frac{D_{\text {middle }}^{2}}{4}\right)
$$

(Huber's eqn. 5)

Where;

$$
\begin{aligned}
& \mathrm{V}=\text { Volume }\left(\mathrm{m}^{3}\right) \\
& \mathrm{H}_{\mathrm{b}}=\text { Bole height }(\mathrm{m}) \\
& \mathrm{L}=\text { Length of lying deadwood section }(\mathrm{m}) \\
& \mathrm{D}_{\text {base }}=\text { Diameter at base }(\mathrm{cm})
\end{aligned}
$$

$\mathrm{D}_{\text {top }}=$ Diameter at top $(\mathrm{cm})$

Dbh $=$ Diameter at breast height $(\mathrm{cm})$

$\pi=$ (pi)

eqn. $=$ equation

\section{Volume estimation of standing and lying dead wood within sample plots}

The mean plot volume for each dead wood in the rainforest ecosystem in Okomu National Park were computed and then multiplied by $0.04(20 \mathrm{~m} \times 20 \mathrm{~m}$ plot in an hectare) to obtain volume per hectare. ${ }^{12}$

\section{Dead wood status}

The decay classes were determined using a "Matchete Test" which assigns dead wood (standing or lying) into one of the three indicators: sound $(\mathrm{S})$, intermediate $(\mathrm{I})$ or rotten $(\mathrm{R})$, by striking the wood with a matchete. ${ }^{13}$ If on striking the deadwood, the matchete;

i. Bounces back, then the pieces is classified as sound (S)

ii. Partly sinks into the dead wood, then it is classified as intermediate (I)

iii. Sinks into the dead wood and the dead wood disintegrates then the dead wood is classified as rotten $(\mathrm{R})$

\section{Data analysis}

Data collected in the rainforest ecosystem were entered and arranged for analysis using Microsoft Excel 2007 version. Descriptive statistics, analysis of variance (ANOVA) and Figures were prepared using MS EXCEL and RStudio.

\section{Results and discussion}

\section{Vegetation structure of standing and lying dead wood}

A total of fourteen lying and twenty one standing dead wood were found in the twelve temporary sample plots laid across the four (4) ranges in the rainforest ecosystem. Hossfeld's equation had the lowest standard error and uncertainty values of 0.39 and $48 \%$ at confidence level of $95 \%$, followed by Geometric equation for the truncated cone with values of 0.42 and $70 \%$, while Smalian's equation had values of 0.44 and $70 \%$, respectively. There were no significant differences amongst the three volume equations with $\mathrm{t}$-Test values of 0.88 , 7.82 and 7.79 for Smalian's equation, Geometric equation for the truncated cone and Hossfeld's equation as presented in Table 1. For the standing dead tree, there was a scale up of volume equations by including Newton's and Huber's equations. Hossfeld's equation had minimum standard error and uncertainty with values of 1.12 and $71 \%$ at confidence level of $95 \%$, followed by Geometric equation for the truncated cone with values of 1.41 and $105 \%$, while Smalian's equation had values of 1.45 and $107 \%$, and Huber's equation had maximum standard error and uncertainty values of 1.68 and $110 \%$, respectively. Newton's equation recorded value of 1.59 and $107 \%$ for standard error and uncertainty. There were no significant differences amongst the five volume equation with $\mathrm{t}-\mathrm{Test}$ values of $0.68,0.86,0.95,0.49$, 0.50 for Newton's equation, Smalian's equation, Hossfeld's equation, Geometric equation for the truncated cone and Huber's equation as presented in Table 2. 
Table I Descriptive statistics of lying dead wood

\begin{tabular}{llll}
\hline & Smalian's $\left(\mathbf{m}^{3}\right)$ & $\begin{array}{l}\text { Geometric equation for the } \\
\text { truncated cone }\left(\mathbf{m}^{3}\right)\end{array}$ & Hossfeld's $\left(\mathbf{m}^{3}\right)$ \\
\hline Mean & 2.32 & 2.24 & 3.04 \\
Standard Error & 0.44 & 0.42 & 0.39 \\
Standard Deviation & 1.63 & 1.57 & 1.45 \\
Sample Variance & 2.66 & 2.46 & 2.11 \\
Minimum & 0.19 & 0.19 & 0.87 \\
Maximum & 5.64 & 5.40 & 5.8 \\
Confidence Level (95.0\%) & 0.94 & 0.91 & 0.84 \\
t-Test & $0.88^{*}$ & $7.82^{*}$ & $7.79^{*}$ \\
Uncertainty & 0.70 & 0.70 & 0.48 \\
\hline
\end{tabular}

Table 2 Descriptive statistics of standing dead wood

\begin{tabular}{|c|c|c|c|c|c|}
\hline & Newton's $\left(\mathrm{m}^{3}\right)$ & Smalian's $\left(\mathrm{m}^{3}\right)$ & Hossfeld's $\left(\mathrm{m}^{3}\right)$ & $\begin{array}{l}\text { Geometric equation for } \\
\text { the truncated cone }\left(\mathrm{m}^{3}\right)\end{array}$ & Huber's $\left(\mathrm{m}^{3}\right)$ \\
\hline Mean & 6.84 & 6.55 & 7.26 & 6.15 & 6.99 \\
\hline Standard Error & 1.59 & 1.45 & 1.12 & $\mathrm{I} .4 \mathrm{I}$ & 1.68 \\
\hline Standard Deviation & 7.31 & 6.65 & 5.14 & 6.46 & 7.70 \\
\hline Sample Variance & 53.37 & 44.28 & 26.41 & 41.72 & 59.30 \\
\hline Minimum & 0.32 & 0.34 & 1.24 & 0.33 & 0.30 \\
\hline Maximum & 28.22 & 26.49 & 21.21 & 25.93 & 29.08 \\
\hline Confidence Level (95.0\%) & 3.33 & 3.03 & 2.34 & 2.94 & 3.51 \\
\hline $\mathrm{t}$-Test & $0.68^{*}$ & $0.86^{*}$ & $0.95^{*}$ & $0.49^{*}$ & $0.50^{*}$ \\
\hline Uncertainty & 1.07 & 1.02 & 0.71 & 1.05 & 1.10 \\
\hline
\end{tabular}

Fraver et al., ${ }^{10}$ found similar results in a study of LDW. Unfortunately, Newton's equation is the most demanding, requiring not only log length but also three cross-sectional area measurements. Therefore, the dynamics of deadwood, standing or lying vary with the type of forest or plantation as well as with the purpose behind protecting a forest or raising a new forest. In fuel wood plantations or community forestry projects, the woody part of the deadwood is likely to be removed and used as fuel wood. However, in the case of avoided deforestation projects involving protection of forests, lying dead wood accumulates on the forest floor. Further, land-use change, particularly from forests and plantations to other land uses such as cropland or grassland, leads to complete loss of dead wood.

\section{Volume estimation of standing and lying dead wood}

The volumes of each dead wood were calculated assuming the tree is a frustum of truncated cone. Hossfeld's equation had the highest total volume estimate of $1.62 \mathrm{~m}^{3} \mathrm{ha}^{-1}$ and $5.07 \mathrm{~m}^{3} \mathrm{ha}^{-1}$ for lying and standing dead wood, while Smalian's equation had value of lying and standing dead wood to be $1.23 \mathrm{~m}^{3} \mathrm{ha}^{-1}$ and $4.42 \mathrm{~m}^{3} \mathrm{ha}^{-1}$, and Geometric equation for the truncated cone recorded values of $1.18 \mathrm{~m}^{3} \mathrm{ha}^{-1}$ and $4.06 \mathrm{~m}^{3} \mathrm{ha}^{-1}$ for lying and standing dead wood, respectively as shown in Table 3 and Table 4. The total volume estimate with Newton's equation and Smalian's equation for standing dead wood had values of $5.01 \mathrm{~m}^{3} \mathrm{ha}^{-1}$ and $5.29 \mathrm{~m}^{3} \mathrm{ha}^{-1}$ as revealed in Table 4 . It corroborates the study by Fraver et al., ${ }^{10}$ who also explored the average-of-ends equation, the conical frustum equation, and a novel conic-paraboloid equation.
Their conic-paraboloid requires no midpoint measurement, showed high accuracy and should be considered for use when lying dead wood methods require volume estimates for individual pieces and economy of measurement is important. Both Smalian's and Huber's equations give inaccurate estimate of volume of stem section which is not truly frustum of paraboloid. Smalian's equation tends to overestimate while Huber's equation under-estimates. The error due to using Smalian's equation is usually twice that of Huber's equation. Smalian's equation is apparently easier to apply especially with regards to felled logs. The accuracy of estimating total or merchantable stem volume by means of either Smalian's and Huber's equations is increased by dividing the stem into a number of short sections and adding together the sectional volumes. $^{10}$

A preliminary regression function was used to define a suitable function that will be used to predict volume of dead wood in the study area. Exponential function was used to fit the five volume equations with a view to identify the most suitable predictor and the relationship amongst the five volume equations considering model selection criteria. There was a very weak relationship amongst the three volume equations for lying dead wood with $\mathrm{R}^{2}$ values of $11 \%$ (Geometric equation for the truncated cone), 9\% (Hossfeld's equation), and 9\% (Smalian's equation), respectively and the five volume equations for standing dead wood with $\mathrm{R}^{2}$ values of $12 \%$ (Newton's equation), $10 \%$ (Huber's equation), 9\% (Hossfeld's equation), 10\% (Geometric equation for the truncated cone), 16\% (Smalian's equation), respectively as presented in Figure 1\&Figure 2. 
Table 3 Volume estimation of lying dead wood

\begin{tabular}{llll}
\hline Range & Smalian's $\left(\mathbf{m}^{3} \mathbf{h a}^{-1}\right)$ & $\begin{array}{l}\text { Geometric equation for the } \\
\text { truncated cone }\left(\mathbf{m}^{3} \mathbf{h a}^{-1}\right)\end{array}$ & Hossfeld's $\left(\mathbf{m}^{3} \mathbf{h a}^{-1}\right)$ \\
\hline A & 0.47 & 0.46 & 0.62 \\
B & 0.39 & 0.37 & 0.46 \\
C & 0.28 & 0.27 & 0.39 \\
D & 0.09 & 0.08 & 0.15 \\
\hline
\end{tabular}

Key: $A$, iguowan range; $B$, arakhuan range; $C$, julius creek range; $D$, baubui creek range

Table 4 Volume estimation of standing dead wood

\begin{tabular}{|c|c|c|c|c|c|}
\hline Range & Newton's $\left(\mathrm{m}^{3} \mathrm{ha}^{-1}\right)$ & Smalian's $\left(\mathrm{m}^{3} \mathrm{ha}^{-1}\right)$ & $\begin{array}{l}\text { Geometric equation for the } \\
\text { truncated cone }\left(\mathrm{m}^{3} \mathrm{ha}^{-1}\right)\end{array}$ & Hossfeld's $\left(\mathrm{m}^{3} \mathrm{ha}^{-1}\right)$ & Huber's $\left(\mathrm{m}^{3} \mathrm{ha}^{-1}\right)$ \\
\hline A & 0.47 & 0.46 & 0.62 & 0.47 & 0.46 \\
\hline B & 0.39 & 0.37 & 0.46 & 0.39 & 0.37 \\
\hline C & 0.28 & 0.27 & 0.39 & 0.28 & 0.27 \\
\hline$D$ & 0.09 & 0.08 & 0.15 & 0.09 & 0.08 \\
\hline
\end{tabular}

Key: $A$, iguowan range; $B$, arakhuan range; $C$, julius creek range; $D$, baubui creek range

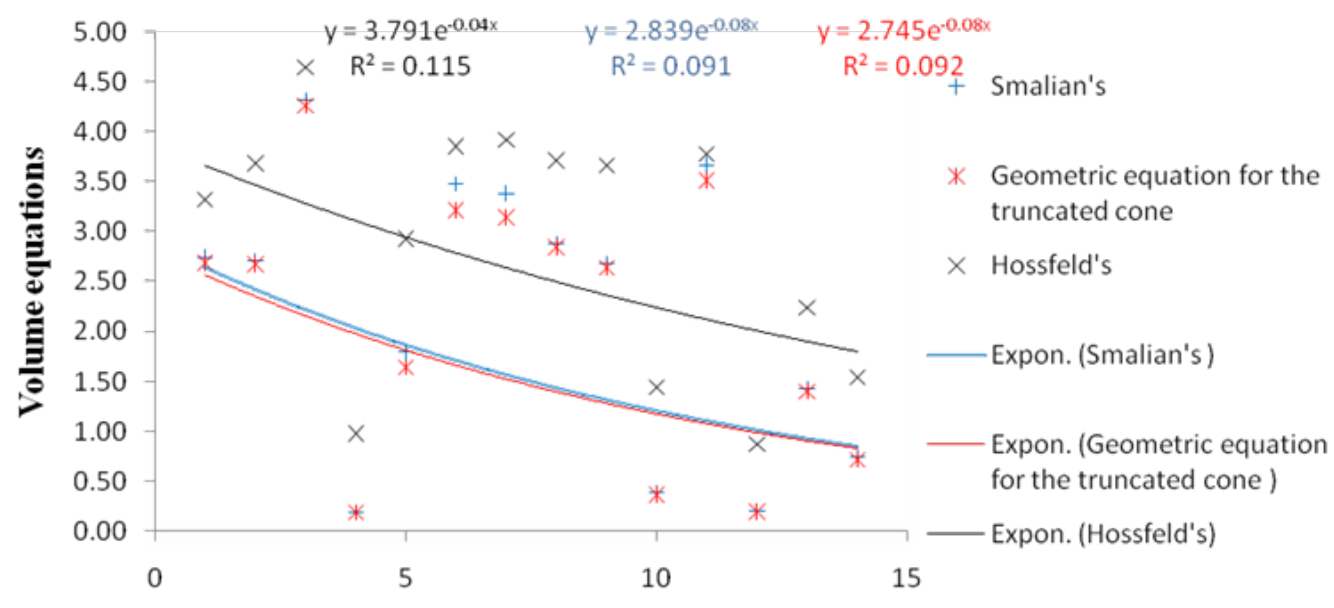

Lying deadwood

Figure I Scattered plots showing the relationship amongst volume equations.

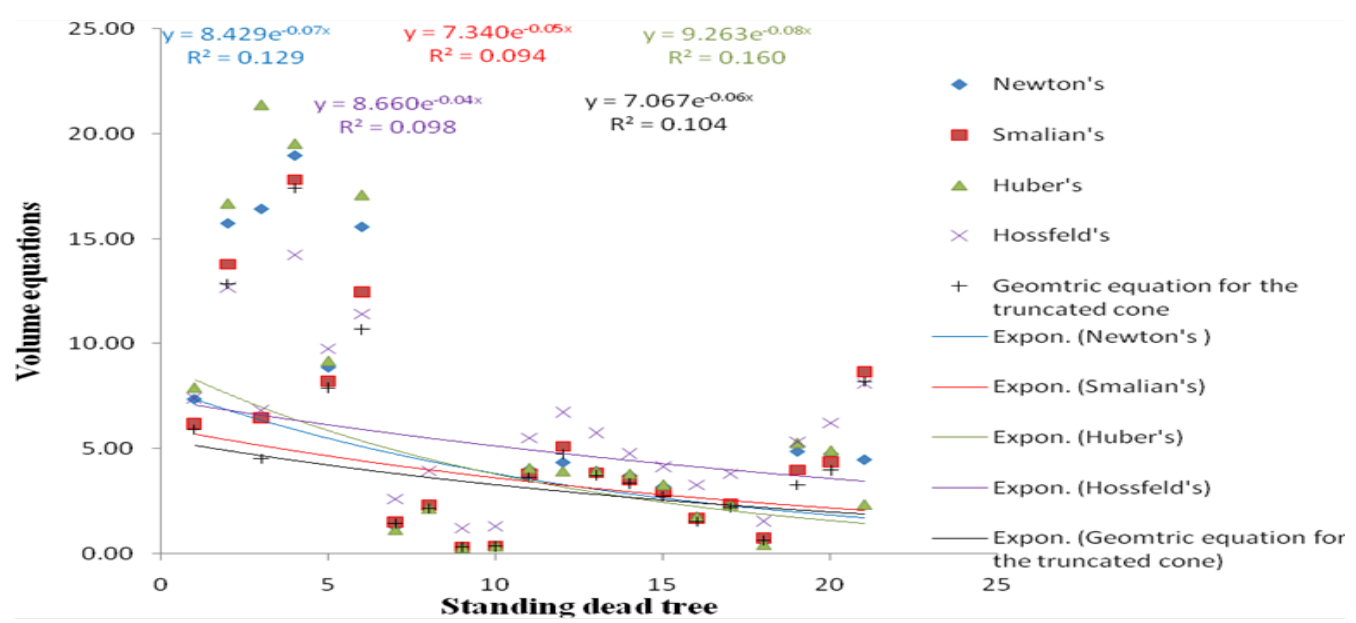

Figure 2 Scattered plots showing the relationship amongst volume equations. 


\section{Forest management in dead wood rainforest ecosystem}

The effect of forest management varies with the ecosystem and the type of activity. Many harvests increase dead wood because tops, limbs, small trees, or cull trees (i.e, slash) are left on-site as a byproduct of removing more economically valuable material (e.g, saw timber). For example, even a $5 \%$ basal-area removal in nature conservation will significantly increase the volume and mass of deadwood. ${ }^{10}$ However, over the long term managed forests often have fewer deadwoods than unmanaged stands. ${ }^{14-16}$ Harvest can also change the distribution of decay classes of lying dead wood and reduce the average piece size of deadwood. ${ }^{10,17}$ Some silvicultural prescriptions call for site preparation, e.g, pilling, windrowing, or scalping to expose

Table 5 Machete test for standing and lying dead wood mineral soil, and such treatments can reduce deadwood over large area. Until recently, dead wood was perceived as a negative element of the forest ecosystems that indicates mismanagement, negligence and wastefulness of the applied forest management. ${ }^{17}$

The first decay class (Sound) represents dead wood, which is least decayed with intact bark, present twigs and branches, round shapes, smooth surface, intact texture, and the position elevated on support points that makes up about $66.67 \%$. As the decay process continues (Intermediate), the twigs, parts of branches and bark become elliptical and it represent about $25 \%$. The last decay class (Rotten) represents the most decomposed deadwood with no bark, twigs or branches, which are very soft, strongly fragmented and in contact with the ground along the whole length and it constitute about $8.33 \%$ as presented in Table 5.

\begin{tabular}{lllllll}
\hline & \multicolumn{2}{c}{ Plot I } & \multicolumn{2}{c}{ Plot 2 } & \multicolumn{2}{c}{ Plot 3 } \\
\hline Range & LDW & SDW & LDW & SDW & LDW & SDW \\
\hline A & R & S & S & S & R & S \\
B & S & S & I & S & S & S \\
C & I & S & I & S & S & I \\
D & S & S & I & S & I & S
\end{tabular}

Key: Sound (S), Intermediate (I), Rotten (R), LDW, lying dead wood, SDW, standing dead wood; Key: A, iguowan range; B, arakhuan range; C, julius creek range; $D$, baubui creek range

\section{Conclusion}

Based on the findings, it is generally accepted that dead wood plays an important role in ecosystem dynamics. It was observed that deadwood constituted a small percentage in the nature conservation of Okomu National Park. However, Hossfeld's equation had the lowest standard error and uncertainty values of 0.39 and $48 \%$ at confidence level of $95 \%$. Although, there were no significant differences amongst the five volume equations with $\mathrm{t}-$ Test values of $0.68,0.86,0.95,0.49$, 0.50 for Newton's equation, Smalian's equation, Hossfeld's equation, Geometric equation for the truncated cone and Huber's equation in lying and standing dead wood. Hossfeld's equation also had the highest total volume estimate of $1.62 \mathrm{~m}^{3} \mathrm{ha}^{-1}$ and $5.07 \mathrm{~m}^{3} \mathrm{ha}^{-1}$ for lying and standing dead wood, but exhibited a very weak relationship to other volume equations with an $\mathrm{R}^{2}$ value of $9 \%$. Therefore, Hossfeld's equation and other volume equations should be considered suitable for estimating volume of standing and lying deadwood, depending on the available variable. Further research should be conducted to further identify the variability in the five volume equations for estimating dead wood.

\section{Acknowledgments}

None

\section{Conflicts of interest}

None

\section{References}

1. Harmon ME, Franklin JF, Swanson FJ, et al. Ecology of coarse woody deris in temperate ecosystems. In: MacFadyen A, Ford ED. Advances in ecological research. Orlando, FL: Academic Press. 1986;15:133-302.
2. MCMinn JW, Crossley DA. Biodiversity and coarse woody debris in southern forests. USDA Southern Research Station, Athens, GA. 1993.

3. Samuelsson J, Gustafsson L, Ingelog T. Dying and dead trees: a review of their importance for biodiversity. Swedish Threatened Species Unit. Uppsala. 1994.

4. Humphrey JW, Sippola AL, Lemperiere G, et al. Deadwood as an indicator of biodiversity in European forests: from theory to operational guidance. EFI-proceedings. 2004;51:193-206.

5. Ducey MJ, Williams MS. Comparison of Hosseld's method and two modern methods for volume estimation of standing trees. West J Appl For. 2011;26(1):19-23.

6. Stokland JN, Tomter SM, Soderberg U. Development of dead wood indicators for biodiversity monitoring: experiences from scandinavia. EFI Proceedings. 2004;51:207-226.

7. Tritton LM. Deadwood in the northern hardwood forest ecosystem. Yale University, New Haven, CT. 1980.

8. Kishwan J, Pandey R. Dadhwal VK. India's forest and tree cover: contributions a carbon sink. Indian council of forestry and education technical paper. ICFRE, Dehradun. 12 pages. 2009.

9. Okomu National Park. Nigeria National Park Service. Retrieved 4 November 2010 .

10. Fraver S, Wagner RG, Day M. Dynamics of coarse woody debris following gap harvesting in the acadian forest of central maine. U.S.A. Canadian journal of forest research. 2002;32(12):2094-2105.

11. Husch B, Beers TW, Kershaw JA. Forest mensuration. John Wiley 8 Sons, Inc, 2003; p. 443.

12. Aghimien EV, James TK. Above-ground bole carbon stock estimation using forest inventory of the secondary forest ecosystem in ibadan, Nigeria. Journal of forestry and management. 2019;16(3):41-49. 
13. McGee GG. Stand-level effect on the role of decaying logs as vascular plant habitat in adirondack northern hardwood forest. The journal of the torrey botanical society. 2001;128(4):370-380.

14. Lesica P, McCune B, Cooper SV, et al. Differences in lichen and bryophyte communities between old-growth and managed $2^{\text {nd }}$-growth forests in the swan valley, Montana. Canadian journal of botany. 1991;69(8):17451755 .

15. Duvall MD, Grigal DF. Effects of timber harvesting on coarse woody debris in red pine forests across the Great Lakes States, U.S.A. Canadian journal of forest research. 29(12):1926-1934.
16. Gibb H, Ball JP, Johansson T, et al. Effects of management on coarse woody debris volume and composition in boreal forests in Northern Sweden. Scandinavian journal of forest research. 2005;20(3):213-222.

17. Stevenson SK, Jull MJ, Rogers BJ. Abundance and attributes of wildlife trees and coarse woody debris at three silvicultural systems study areas in the Interior Cedar-Hemlock Zone, British Columbia. Forest ecology and management. 2006;233(1):176-191. 